\title{
Factorial analysis of slaughter characteristics of fattening pigs fed different additives - Enzyme and probiotic in mixtures
}

\author{
Blazenka Popovic ${ }^{1 \star}$, Branislav Zivkovic ${ }^{2}$, Radojka Maletic ${ }^{1}$, Zoran Rajic ${ }^{1}$ and \\ Svjetlana Jankovic-Soja ${ }^{1}$ \\ ${ }^{1}$ University of Belgrade, Faculty of Agriculture, Nemanjina 6, 11080 Belgrade - Zemun, Serbia. \\ ${ }^{2}$ Institute for Animal Husbandry, Autoput 16, 11080 Belgrade - Zemun, Serbia.
}

Accepted 13 June, 2011

\begin{abstract}
To successfully investigate slaughter characteristics of fattening pigs fed in different ways, this experiment was carried out on Experimental Farm of the Institute for Animal Husbandry, BelgradeZemun. Investigation of correlation between slaughter traits of pigs fed with different additives in their nutrition was done by factorial analysis. Slaughter characteristics in three groups of fattening pigs fed in different ways were observed. The first group (variant 1) consisted of fatteners fed diets without any special additives. The second group (variant 2) consisted of pigs fed diets containing enzyme Rovabio, and the third group (variant 3 ) probiotic Lacture + Microbond. This study was aimed at coming to conclusion based on the results of factorial analysis of the observed traits to the greatest extent which determined slaughter traits of pigs fed diets containing different additives. The results obtained in general, that is, the structure of separated factors showed that different slaughter characteristics are realized with different nutrition.
\end{abstract}

Key words: Fattening pigs, slaughter characteristics, enzyme Rovabio, probiotic Lacture + Microbond, factorial analysis.

\section{INTRODUCTION}

Probiotic preparations are used as food additives containing live micro organisms, used to replace or supplement micro flora of the digestive tract and protection of the animal health. The aim of their use is to reduce the utilization of antibiotics in animal nutrition, as much as possible, and that products are free of harmful residues. As a result, the following is realized: Increase of milk performance and of body mass, animal resistance, better use of nutrients, products of higher quality are obtained and environment is protected. Enzyme preparations are used in animal nutrition in order to improve the digestibility of food that is, increase the nutritional value of animal food. Multi-applicative solutions contribute to improvement of animal performances, enable use of more raw materials in nutrition and reduce phosphorus

*Corresponding author. E-mail: blazenka@agrif.bg.ac.rs. Tel: +381112615315. Fax: +381113161730. emission on the farm (Gardzińska et al., 2003; Fililz et al., 2008; Nortey et al., 2007; Kosovac et al., 2006).

The influence of different genetic characteristic, as well as of food additions, is a topic of numerous researches (Collins et al., 2007; Ostrowska et al., 2005; Zivkovic et al., 2003c, 2006c) that are very important for improving slaughter characteristics of fattening pigs. Considering our positive experiences with the use of probiotics in nutrition of sows and piglets (Zivkovic et al., 2003a, b, 2004a, b, 2006b, d; Radovic et al., 2007), as well as layer hens in production of table. The objective of this study was to investigate the effects of introduction of enzyme Rovabio and probiotic Lacture, based on yeast cultures Saccharmoyces cerevisiae and bacteria of lactic acid, enzymes and manane oligosaccharides, as well as Microbond, based on D-glucanes, in nutrition of fattening pigs (Xin et al., 2007; Angelov et al., 2010; WiniarskaMieczan and Kwiecien, 2010). Complete, clear and profound understanding of correlation between observed slaughter traits of fattening pigs can be achieved through 
the application of the method of factorial analysis, representing a set of mathematical-statistical procedures which enable that based on numerous mutually dependent and correlated variables less latent variables are determined which explain existing correlation. These fundamental variables which can elicit great number of mutually related variables are called factors. In this way, important task of factorial analysis is achieved as well as determination of homogeneity of observed characteristics (Fulgosi, 1979). At the same time, this means reduction of the number of properties, which is also a significant contribution of the application of this method. If intercorrelation of traits is higher, factorization is more expressed, that is, number of factors is lower, and amount of information which they contain on initial traits is greater (Ivanovic, 1977; Maletic, 2000).

\section{MATERIALS AND METHODS}

Investigations were carried out on Experimental Pig Farm of the Institute for Animal Husbandry, Belgrade-Zemun. Trial included total of 30 heads divided into three groups. According to present technology on the farm, and based on standard criteria of origin, sex and initial mass, animals were divided into three groups of 10 , that is, three nutrition treatments.

First, control group received diet of standard composition used on the pig farm. Secondly, trial group of animals was fed the same diet supplemented with enzyme Rovabio, and thirdly, trial group was fed standard diet supplemented with probiotic Lacture and Microbond. Pigs received food ad libitum during entire trial period and received water from automatic waterers. All analyzes were done with software Stat Soft STATISTICA 8.0 for Windows.

Analyzed data relate to slaughter traits of pigs fed in three ways, that is, with different feed additives. 46 slaughter traits were observed for each of three nutrition methods, viz: $x_{1}$ - body mass of pigs prior to slaughtering $(\mathrm{kg}) ; \mathrm{x}_{2}$ - mass of warm carcass sides $(\mathrm{kg})$; $\mathrm{x}_{3}-$ fat thickness, withers $(\mathrm{mm}) ; \mathrm{x}_{4}-$ fat thickness, back $(\mathrm{mm}) ; \mathrm{x}_{5}-$ fat thickness, rump $(\mathrm{mm}) ; x_{6}-$ carcass length, atlas- pubis $(\mathrm{cm}) ; x_{7}-$ carcass length, $1^{\text {st }}$ rib- pubis $(\mathrm{cm}) ; x_{8}$-dressing percentage $(\%) ; x_{9}-$ meat yield $(\%) ; x_{10}$ - leg $(g) ; x_{11}$ - shoulder $(g) ; x_{12}$ - back + fat tissue (g); $x_{13}$ - rib fat $(g) ; x_{14}$ - butt shoulder with neck $(g) ; x_{15}$ - belly fat $(g)$; $x_{16}-$ fore thigh $(g)$; $x_{17^{-}}$kidney $(g)$; $x_{18^{-}}$shank $(g)$; $x_{19^{-}}$feet $(g)$; $\mathrm{x}_{20}-$ kidney fat $(\mathrm{g}) ; \mathrm{x}_{21}-$ head $(\mathrm{g}) ; \mathrm{x}_{22}-$ tender loin $(\mathrm{g}) ; \mathrm{x}_{23}-$ Jowl $(\mathrm{g})$; $x_{24}-$ front ribs in butt shoulder with neck $(g) ; x_{25}-$ meat for smoking in butt shoulder with neck $(\mathrm{g}) ; \mathrm{x}_{26}$ - cut meat in butt shoulder with neck $(g) ; x_{27}-$ fat tissue in butt shoulder with neck $(g) ; x_{28^{-}}$skin in butt shoulder with neck $(\mathrm{g})$; $\mathrm{x}_{29}-$ bones with $30 \%$ of meat in butt shoulder with neck, $(\mathrm{g})$; $x_{30}-$ MLD loin part of the back $(g) ; x_{31}$ - cut meat in loin part of the back $(g)$; $x_{32}-$ fat tissue in loin part of the back $(\mathrm{g}) ; x_{33}-$ skin in loin part of the back $(\mathrm{g})$; $x_{34}-$ bones in loin part of the back $(\mathrm{g}) ; \mathrm{x}_{35}-$ meat in the leg $(\mathrm{g}) ; \mathrm{x}_{36}-$ fat tissue in the leg $(\mathrm{g})$; $x_{37}-$ skin in the leg $(g) ; x_{38}-$ bones in the leg $(g) ; x_{39}-$ meat in the shoulder $(g) ; x_{40}-$ fat in the shoulder $(g) ; x_{41}-$ skin in the shoulder $(g) ; x_{42}-$ bones in the shoulder $(g) ; x_{43}-$ meat in rib fat tissue $(g)$; $\mathrm{x}_{44}-\mathrm{fat}$ in rib fat tissue $(\mathrm{g}) ; \mathrm{x}_{45}-\mathrm{skin}$ in rib fat tissue $(\mathrm{g})$; $\mathrm{X}_{46}-$ bones in rib fat tissue $(\mathrm{g})$.

\section{Statistical analysis}

For the obtained experimental data, descriptive statistics parameters have been defined first, and then the Pearson's correlation coefficients, in order to detect the correlation in slaughter characteristics by using different feeding methods (Popovic, 2001).

The objective of the factorial analysis is to explain the mutual correlation between large number of variables with fewer fundamental variables (Lakic, 1984; Stankovic et al., 1985; Popovic, 2005; Ralevic et al., 2006). Main task of the factorial analysis is to extract from initial set of indicators $\left(x_{1}, x_{2}, \ldots x_{n}\right)$ fewer $(p<n)$ latent (hidden) factors $\left(F_{1}, F_{2} \ldots F_{p}\right)$, so the model of factorial analysis can be written down in the following form

$$
X_{j}=\sum_{k-1}^{p} a_{j k} F_{k}+\varepsilon_{j} \mathrm{j}=1,2, \ldots \mathrm{n}
$$

Where, $a_{j k}$ represent factorial load of $k$ latent factor on $j$ indicator, and $\varepsilon_{\mathrm{j}}$ so called specific factors, that is, residual random components.

Factorial analysis was carried out using the method of main factors where analysis of main components is applied on complete correlation matrix. Based on established characteristic equations and their square roots by Kaiser criteria, the number of factors which are maintained as relevant for further analysis is determined (only common factors with characteristic square root greater than 1 (one) are maintained). After that orthogonal rotation of primary factorial solution using Kaiser varimax method was performed. By rotation, a factorial matrix was obtained whose elements are factorial ponders, and ponders of value above 0.7 are considered significant and based on their correlation with certain factor a factor interpretation was carried out. Methodology reveals that in the first factor the highest proportional share of total variation of all 46 traits is located, and in subsequent factors this proportion decreases.

\section{RESULTS AND DISCUSSION}

Average level and variability of observed slaughter characteristics for all three nutrition methods are presented in Table 1.

Variability of observed traits was expressed by variation coefficient and it is almost low and below 30\%, which indicated that these are homogenous series of data.

\section{Correlation analysis}

According to results of correlation analysis, correlation between slaughter properties realized in different nutrition treatments is similar.

In case of first nutrition treatment, a very high negative correlation between the following indicators is observed: Fat thickness at withers and rump fat thickness; belly fat and butt shoulder with neck; head and shank; jowl and body mass of pigs prior to slaughtering; kidney fat and front ribs in butt shoulder with neck; fat in rib fat tissue and fat thickness (withers) etc. Very high positive correlation exists between the following characteristics: leg mass and body mass prior to slaughtering and mass of warm carcass sides; jowl and body mass of pigs prior to slaughtering; back fat and rump fat thickness; fat of the leg and carcass length (atlas-pubis); kidney fat and fat of the leg, etc.

In case of the second nutrition treatment, very high 
Table 1. Indicators of the average level and variability of slaughter characteristics.

\begin{tabular}{|c|c|c|c|c|c|c|c|c|c|}
\hline \multirow{2}{*}{ Indicator } & \multicolumn{3}{|c|}{ Variant 1} & \multicolumn{3}{|c|}{ Variant 2} & \multicolumn{3}{|c|}{ Variant 3} \\
\hline & $\bar{x}$ & S & $\mathrm{C}_{\mathrm{v}}(\%)$ & $\bar{x}$ & S & $\mathbf{C}_{\mathrm{v}}(\%)$ & $\bar{x}$ & S & $\mathbf{C}_{\mathrm{v}}(\%)$ \\
\hline$x_{1}$ & 97.4 & 1.96 & 2.012 & 98.4 & 3.72 & 3.781 & 98.5 & 2.1679 & 2.201 \\
\hline$x_{2}$ & 76.3 & 1.503 & 1.97 & 74.6 & 2.82 & 3.777 & 75.33 & 2.5232 & 3.349 \\
\hline$x_{3}$ & 32.6 & 3.72 & 11.41 & 29.2 & 2.79 & 9.54 & 34.83 & 4.2622 & 12.24 \\
\hline $\mathrm{x}_{4}$ & 19.6 & 1.625 & 8.29 & 17.6 & 2.5 & 14.19 & 16.67 & 2.582 & 15.49 \\
\hline$x_{5}$ & 20.6 & 3.382 & 16.42 & 20.8 & 3.43 & 16.49 & 16.67 & 3.6148 & 21.69 \\
\hline$x_{6}$ & 97.0 & 1.789 & 1.844 & 95.6 & 3.61 & 3.777 & 96 & 1.7607 & 1.834 \\
\hline$x_{7}$ & 80.7 & 2.088 & 2.587 & 79 & 5.4 & 6.84 & 80.5 & 0.8367 & 1.039 \\
\hline $\mathrm{X}_{8}$ & 78.342 & 0.876 & 1.118 & 75.826 & 1.52 & 2.009 & 76.49 & 2.1707 & 2.838 \\
\hline $\mathrm{X}_{9}$ & 41.706 & 0.888 & 2.13 & 42.668 & 1.2 & 2.821 & 43.57 & 1.0939 & 2.511 \\
\hline$x_{10}$ & 8208 & 220.9 & 2.691 & 8055 & 346 & 4.291 & 8147 & 426.22 & 5.232 \\
\hline$x_{11}$ & 4576 & 444.6 & 9.716 & 4704 & 323 & 6.859 & 4676 & 417.28 & 8.924 \\
\hline$x_{12}$ & 5688 & 428.3 & 7.53 & 5729 & 333 & 5.812 & 5493 & 576.11 & 10.49 \\
\hline$x_{13}$ & 4084 & 181.3 & 4.439 & 3984 & 341 & 8.553 & 3838 & 260.61 & 6.791 \\
\hline$x_{14}$ & 5018 & 822 & 16.38 & 5159 & 146 & 2.835 & 5132 & 716.56 & 13.96 \\
\hline$x_{15}$ & 2364 & 209.2 & 8.851 & 2227 & 142 & 6.381 & 2265 & 201.67 & 8.904 \\
\hline$x_{16}$ & 729 & 26.91 & 3.691 & 772 & 62.4 & 8.085 & 765 & 38.859 & 5.08 \\
\hline$x_{17}$ & 160 & 23.66 & 14.79 & 157 & 26.2 & 16.68 & 175.8 & 29.055 & 16.52 \\
\hline$x_{18}$ & 1360 & 88.99 & 6.544 & 1445 & 155 & 10.73 & 1422 & 135.08 & 9.502 \\
\hline$x_{19}$ & 684 & 37.2 & 5.439 & 707 & 47.9 & 6.777 & 702.5 & 36.021 & 5.128 \\
\hline $\mathrm{x}_{20}$ & 750 & 178.1 & 23.75 & 583 & 149 & 25.54 & 657.5 & 186.19 & 28.32 \\
\hline$x_{21}$ & 1970 & 40.99 & 2.081 & 1840 & 201 & 10.91 & 2032 & 203.9 & 10.04 \\
\hline$x_{22}$ & 337 & 41.9 & 12.43 & 349 & 35 & 10.02 & 345.8 & 30.069 & 8.695 \\
\hline$x_{23}$ & 726 & 133.2 & 18.35 & 686 & 99.3 & 14.47 & 727.5 & 164.67 & 22.64 \\
\hline$x_{24}$ & 537 & 70.11 & 13.06 & 589 & 65 & 11.03 & 511.7 & 42.151 & 8.238 \\
\hline$x_{25}$ & 1412 & 168.9 & 11.96 & 1708 & 156 & 9.135 & 1632 & 200.44 & 12.28 \\
\hline$x_{26}$ & 1068 & 77.05 & 7.214 & 1315 & 57.3 & 4.355 & 1240 & 262.81 & 21.19 \\
\hline$x_{27}$ & 773 & 215.4 & 27.87 & 591 & 169 & 28.66 & 854.2 & 426.95 & 49.98 \\
\hline$x_{28}$ & 193 & 51.34 & 26.6 & 141 & 25 & 17.72 & 238.3 & 127.97 & 53.69 \\
\hline$x_{29}$ & 651 & 135.9 & 20.87 & 801 & 55.4 & 6.911 & 709.2 & 138.36 & 19.51 \\
\hline$x_{30}$ & 2284 & 367.7 & 16.1 & 2262 & 269 & 11.89 & 2180 & 151.33 & 6.942 \\
\hline$x_{31}$ & 939 & 68.29 & 7.273 & 1024 & 249 & 24.34 & 885 & 354.1 & 40.01 \\
\hline$x_{32}$ & 1190 & 263 & 22.1 & 1024 & 249 & 24.34 & 1123 & 339.33 & 30.21 \\
\hline$x_{33}$ & 234 & 42.12 & 18 & 251 & 44.3 & 17.66 & 256.7 & 68.093 & 26.53 \\
\hline$x_{34}$ & 1019 & 114.8 & 11.27 & 1127 & 132 & 11.72 & 1028 & 174.64 & 17 \\
\hline$x_{35}$ & 5951 & 367.9 & 6.182 & 5912 & 332 & 5.614 & 5955 & 417.65 & 7.013 \\
\hline$x_{36}$ & 1315 & 281.1 & 21.38 & 1009 & 189 & 18.7 & 1108 & 161.54 & 14.58 \\
\hline$x_{37}$ & 346 & 29.39 & 8.495 & 355 & 37.9 & 10.69 & 351.7 & 60.553 & 17.22 \\
\hline$x_{38}$ & 708 & 39.19 & 5.536 & 752 & 52.7 & 7.006 & 702.5 & 30.943 & 4.405 \\
\hline$x_{39}$ & 2909 & 325.7 & 11.2 & 2814 & 314 & 11.15 & 2937 & 262.42 & 8.936 \\
\hline$x_{40}$ & 1133 & 339.6 & 29.97 & 1067 & 76.4 & 7.16 & 944.2 & 136.62 & 14.47 \\
\hline $\mathrm{x}_{41}$ & 289 & 36.8 & 12.73 & 285 & 44.3 & 15.53 & 301.7 & 134.19 & 44.48 \\
\hline $\mathrm{X}_{42}$ & 478 & 29.93 & 6.262 & 525 & 21.4 & 4.085 & 515 & 36.056 & 7.001 \\
\hline $\mathrm{x}_{43}$ & 2186 & 108.6 & 4.966 & 2275 & 231 & 10.17 & 2188 & 157.28 & 7.187 \\
\hline$x_{44}$ & 1320 & 163.3 & 12.37 & 1073 & 214 & 19.94 & 1127 & 226.77 & 20.13 \\
\hline $\mathrm{X}_{45}$ & 304 & 28.71 & 9.443 & 335 & 40.2 & 12.01 & 285 & 70.64 & 24.79 \\
\hline $\mathrm{X}_{46}$ & 242 & 27.31 & 11.29 & 256 & 58.2 & 22.72 & 230.8 & 30.727 & 13.31 \\
\hline
\end{tabular}


negative correlation was observed between the following characteristics: Fat thickness (back) and meat yield; fat thickness (back) and leg; fat thickness (back) and meat in the leg; dressing percentage and fat in the shoulder; leg and bones in loin part of the back; dressing percentage and fat in shoulder, etc. High positive correlation was recorded between the following characteristics: body mass of pigs prior to slaughter and meat yield; body mass of pigs prior to slaughtering and leg meat; mass of warm carcass sides and leg; mass of warm carcass sides and shoulder; carcass length (atlas-pubis) and leg; meat yield and meat in the leg; shoulder and cut meat of butt shoulder with neck; shoulder and meat in the shoulder, etc.

Inter correlation of slaughter characteristics in case of third nutrition treatment is somewhat lower than in two previous cases, and very high negative correlation is recorded for: fat thickness (back) and meat yield; fat thickness (back) and leg; butt shoulder with neck and fat in shoulder. High positive correlation was recorded between the following characteristics: body mass of pigs prior to slaughtering and kidney fat; carcass length (ribpubis) and dressing percentage; dressing percentage and leg; meat yield and leg; shoulder and meat in shoulder, etc.

\section{Factorial analysis}

Factorization in the first and second variants of nutrition was finalized by the fourth factor, and in the third variant by fifth factor (since only common factors with characteristic square root over 1 are maintained) which include $100 \%$ of total variation of observed traits.

Distribution of total variability of slaughter properties per individual factors is presented in Table 2.

In regard to dispersion distribution per individual factors, it is obvious that most were included in the first factor, over $30 \%$; the second factor included somewhat lower percentage of total variation varying from $25.78 \%$ in the third nutrition treatment, $27.54 \%$ in the first variant and $28.26 \%$ in the second nutrition variant. Proportional share of remaining factors in total variation is increasingly lower, so that in the third factor it is approximately $20 \%$, and in the fourth factor it varied from 10.34 to $14.38 \%$.

Subsequent to rotation of initial factorial matrix, factors were obtained which were adequate for interpretation; and considering their correlation with initial indicators, they were interpreted.

Slaughter traits in the first nutrition treatment (variant 1) distributed themselves in four factors, where the first factor included $38.22 \%$ of total variability. In the structure of this factor, the following traits were dominant: Fat thickness, withers; fat thickness, rump; belly fat; fat tissue in butt shoulder with neck; fat in loin part of the back; fat in rib fat tissue; so it can be concluded that the first factor was the one defining the fat. The second factor explained
$27.54 \%$ of total variability, and in the structure of this factor the following traits are dominant: meat yield; tender loin; meat in the rib fat tissue; so the second factor can be defined as meat yield. The third factor explained $19.85 \%$ of total variability, and considering the correlation with the initial traits it can be defined as factor skin (skin in loin part of the back, skin in the shoulder, skin in the rib fat tissue). Traits which were related with fourth factor mainly related to shoulder and butt shoulder traits, therefore this factor explained $14.38 \%$ of total variability.

In the second nutrition treatment (variant 2), traits were distributed also within four factors, where the first factor explained $39.65 \%$ of total variability. This factor can be defined as meat yield since the following traits were related to this factor: meat yield; leg; shoulder; tender loin; leg meat; shoulder meat; rib fat tissue meat. The second factor could be defined as the fat factor since most of the traits related to this factor related also to fat (kidney fat; jowl; fat tissue in the leg). This factor explained $28.26 \%$ of total variability. The third factor was dominated by traits relating to skin and bones, and this factor explained $21.75 \%$ of total variability. The fourth factor explained $10.34 \%$ of total data dispersion and was mainly defined by traits relating to loin part of the back.

The third nutrition treatment (variant 3 ), contrary to previous two, resulted in the separation of five factors. The first factor explained $31.53 \%$ of total variation, and most traits connected to this factor related to meat yield (meat yield; leg; butt shoulder with neck; meat in the leg; meat for drying in butt shoulder with neck). The second factor was dominated by traits related to fat tissue (fat thickness, withers; rib fat tissue; kidney fat; fat tissue in butt shoulder with neck; fat tissue in loin part of the back), and this factor explained $25.78 \%$ of total variability. Traits connected to shoulder defined the third factor and this factor explained $18.91 \%$ of total variation. The fourth factor explained $12.97 \%$, and the fifth $10.81 \%$ of total variability. Traits related to these factors are very heterogeneous so it was not possible to define their names.

Part of total variance explained by separated factors for each observed slaughter characteristic and each nutrition treatment is presented in Table 3.

\section{Conclusion}

Investigation of correlation between 46 slaughter characteristics of pigs fed diets containing different additives showed that observed traits do not present uniform set. By correlation analysis, it was determined that between observed traits there was expressed inter-correlation which resulted from extraction of fewer factors. In case of first and second nutrition treatment, four factors per each treatment were separated, and in the third treatment, due to somewhat lower correlation between indicators, five factors were separated. Structure of formed factors 
Table 2. Distribution of variability of properties per individual factors

\begin{tabular}{|c|c|c|c|c|c|c|c|c|c|}
\hline \multirow[b]{2}{*}{ Factor } & \multicolumn{3}{|c|}{ Variant 1} & \multicolumn{3}{|c|}{ Variant 2} & \multicolumn{3}{|c|}{ Variant 3} \\
\hline & $\begin{array}{c}\text { Characteristic } \\
\text { square root }\end{array}$ & $\begin{array}{l}\% \text { of total } \\
\text { variation }\end{array}$ & $\begin{array}{c}\text { Cumulant } \\
(\%)\end{array}$ & $\begin{array}{c}\text { Characteristic } \\
\text { square root }\end{array}$ & $\begin{array}{l}\% \text { of total } \\
\text { variation }\end{array}$ & $\begin{array}{c}\text { Cumulant } \\
(\%)\end{array}$ & $\begin{array}{c}\text { Characteristic } \\
\text { square root }\end{array}$ & $\begin{array}{l}\% \text { of total } \\
\text { variation }\end{array}$ & $\begin{array}{c}\text { Cumulant } \\
(\%)\end{array}$ \\
\hline 1 & 17.58 & 38.22 & 38.22 & 18.24 & 39.65 & 39.65 & 14.50 & 31.53 & 31.53 \\
\hline 2 & 12.67 & 27.54 & 65.76 & 13.00 & 28.26 & 67.91 & 11.86 & 25.78 & 57.31 \\
\hline 3 & 9.13 & 19.85 & 85.62 & 10.00 & 21.75 & 89.66 & 8.70 & 18.91 & 76.22 \\
\hline 4 & 6.61 & 14.38 & 100.00 & 4.75 & 10.34 & 100.00 & 5.97 & 12.97 & 89.19 \\
\hline 5 & 1 & I & I & 1 & I & 1 & 4.97 & 10.81 & 100.00 \\
\hline
\end{tabular}

Table 3. Communalities (\%) of slaughter characteristics for different nutrition treatments

\begin{tabular}{|c|c|c|c|c|c|c|c|c|c|c|c|c|c|}
\hline \multirow[b]{2}{*}{ Trait } & \multicolumn{4}{|c|}{ Variant 1} & \multicolumn{4}{|c|}{ Variant 2} & \multicolumn{5}{|c|}{ Variant 3} \\
\hline & $\begin{array}{l}\text { For first } \\
\text { factor }\end{array}$ & $\begin{array}{l}\text { For two } \\
\text { factor }\end{array}$ & $\begin{array}{l}\text { For three } \\
\text { factor }\end{array}$ & $\begin{array}{l}\text { For four } \\
\text { factor }\end{array}$ & $\begin{array}{l}\text { For first } \\
\text { factor }\end{array}$ & $\begin{array}{l}\text { For two } \\
\text { factor }\end{array}$ & $\begin{array}{l}\text { For three } \\
\text { factor }\end{array}$ & $\begin{array}{l}\text { For four } \\
\text { factor }\end{array}$ & $\begin{array}{c}\text { For } \\
\text { first } \\
\text { factor }\end{array}$ & $\begin{array}{l}\text { For two } \\
\text { factor }\end{array}$ & $\begin{array}{l}\text { For three } \\
\text { factor }\end{array}$ & $\begin{array}{l}\text { For four } \\
\text { factor }\end{array}$ & $\begin{array}{l}\text { For first } \\
\text { factor }\end{array}$ \\
\hline$x_{1}$ & 66.9 & 92.2 & 95.4 & 100 & 74.4 & 84.7 & 85.3 & 100 & 0.1 & 96.0 & 99.2 & 99.2 & 100 \\
\hline$x_{2}$ & 33.7 & 86.1 & 94.0 & 100 & 91.1 & 91.4 & 96.2 & 100 & 60.4 & 86.2 & 91.1 & 91.1 & 100 \\
\hline$x_{3}$ & 66.1 & 66.2 & 73.6 & 100 & 25.5 & 71.9 & 96.4 & 100 & 8.1 & 88.7 & 88.8 & 88.8 & 100 \\
\hline$x_{4}$ & 0.0 & 72.8 & 94.1 & 100 & 53.6 & 57.2 & 62.8 & 100 & 92.2 & 93.0 & 98.1 & 98.1 & 100 \\
\hline$x_{5}$ & 49.7 & 59.5 & 59.5 & 100 & 33.3 & 55.1 & 55.2 & 100 & 2.8 & 39.9 & 49.9 & 49.9 & 100 \\
\hline$x_{6}$ & 0.0 & 0.4 & 0.7 & 100 & 86.7 & 87.9 & 95.3 & 100 & 34.8 & 50.0 & 51.5 & 51.5 & 100 \\
\hline$x_{7}$ & 0.5 & 1.4 & 26.6 & 100 & 56.7 & 56.8 & 83.6 & 100 & 57.3 & 58.9 & 59.4 & 59.4 & 100 \\
\hline$x_{8}$ & 19.4 & 33.2 & 99.7 & 100 & 3.6 & 54.7 & 87.3 & 100 & 79.2 & 81.8 & 83.5 & 83.5 & 100 \\
\hline$X_{9}$ & 21.9 & 84.0 & 86.5 & 100 & 59.6 & 61.2 & 65.2 & 100 & 86.5 & 90.9 & 95.8 & 95.8 & 100 \\
\hline$x_{10}$ & 49.2 & 80.2 & 80.4 & 100 & 81.9 & 88.1 & 88.1 & 100 & 87.0 & 92.4 & 95.5 & 95.5 & 100 \\
\hline$x_{11}$ & 6.1 & 19.7 & 26.6 & 100 & 79.6 & 89.6 & 96.5 & 100 & 8.1 & 8.7 & 92.0 & 92.0 & 100 \\
\hline$x_{12}$ & 0.9 & 77.4 & 91.9 & 100 & 14.6 & 16.6 & 99.8 & 100 & 1.1 & 47.7 & 53.9 & 53.9 & 100 \\
\hline$x_{13}$ & 10.5 & 55.8 & 59.6 & 100 & 71.4 & 98.3 & 98.8 & 100 & 4.4 & 63.2 & 63.8 & 63.8 & 100 \\
\hline$x_{15}$ & 51.6 & 52.9 & 98.8 & 100 & 47.5 & 55.3 & 99.3 & 100 & 0.2 & 7.3 & 8.4 & 8.4 & 100 \\
\hline$x_{16}$ & 95.5 & 97.6 & 99.5 & 100 & 19.8 & 91.0 & 93.8 & 100 & 15.2 & 17.9 & 18.9 & 18.9 & 100 \\
\hline$x_{17}$ & 83.3 & 87.1 & 98.2 & 100 & 0.6 & 35.7 & 55.4 & 100 & 6.6 & 30.3 & 54.3 & 54.3 & 100 \\
\hline$x_{18}$ & 0.1 & 90.5 & 91.1 & 100 & 35.3 & 44.6 & 90.5 & 100 & 4.4 & 8.5 & 77.3 & 77.3 & 100 \\
\hline$x_{19}$ & 6.3 & 69.6 & 96.2 & 100 & 14.6 & 54.0 & 96.0 & 100 & 2.4 & 12.7 & 12.9 & 12.9 & 100 \\
\hline$x_{20}$ & 2.9 & 3.6 & 4.4 & 100 & 3.1 & 92.1 & 99.1 & 100 & 2.0 & 98.1 & 99.0 & 99.0 & 100 \\
\hline$x_{21}$ & 5.2 & 90.0 & 95.6 & 100 & 4.7 & 89.8 & 99.4 & 100 & 86.0 & 86.1 & 95.0 & 95.0 & 100 \\
\hline
\end{tabular}


Table 3.continues.

\begin{tabular}{|c|c|c|c|c|c|c|c|c|c|c|c|c|c|}
\hline$x_{22}$ & 0.3 & 90.5 & 100.0 & 100 & 54.2 & 98.9 & 98.9 & 100 & 34.7 & 38.6 & 42.9 & 42.9 & 100 \\
\hline$x_{23}$ & 86.2 & 99.2 & 99.9 & 100 & 8.7 & 59.1 & 79.2 & 100 & 4.2 & 5.6 & 15.5 & 15.5 & 100 \\
\hline$x_{24}$ & 16.0 & 26.8 & 33.8 & 100 & 2.8 & 5.9 & 17.5 & 100 & 19.3 & 23.4 & 99.5 & 99.5 & 100 \\
\hline$x_{26}$ & 12.0 & 49.8 & 50.6 & 100 & 70.9 & 98.4 & 100.0 & 100 & 12.8 & 63.7 & 82.1 & 82.1 & 100 \\
\hline$x_{27}$ & 56.2 & 65.3 & 71.1 & 100 & 0.4 & 1.4 & 94.4 & 100 & 20.3 & 70.9 & 80.2 & 80.2 & 100 \\
\hline$x_{28}$ & 37.3 & 40.2 & 44.1 & 100 & 24.1 & 96.0 & 97.6 & 100 & 0.0 & 50.5 & 81.1 & 81.1 & 100 \\
\hline$x_{29}$ & 5.0 & 6.6 & 100.0 & 100 & 0.4 & 25.7 & 97.5 & 100 & 17.2 & 25.1 & 68.6 & 68.6 & 100 \\
\hline$x_{30}$ & 13.2 & 80.0 & 96.7 & 100 & 76.7 & 78.2 & 95.8 & 100 & 1.5 & 18.8 & 99.9 & 99.9 & 100 \\
\hline$x_{31}$ & 87.8 & 97.1 & 97.3 & 100 & 11.2 & 11.9 & 12.1 & 100 & 28.7 & 31.4 & 54.3 & 54.3 & 100 \\
\hline$x_{32}$ & 65.2 & 65.3 & 65.4 & 100 & 11.2 & 11.9 & 12.1 & 100 & 13.4 & 81.5 & 84.2 & 84.2 & 100 \\
\hline$x_{33}$ & 6.0 & 15.8 & 94.5 & 100 & 3.9 & 37.4 & 87.2 & 100 & 4.8 & 70.3 & 78.0 & 78.0 & 100 \\
\hline$x_{34}$ & 3.4 & 75.1 & 75.5 & 100 & 64.1 & 70.5 & 70.5 & 100 & 1.1 & 4.3 & 8.3 & 8.3 & 100 \\
\hline$x_{36}$ & 1.0 & 4.2 & 8.7 & 100 & 1.4 & 65.0 & 65.1 & 100 & 0.7 & 3.0 & 7.1 & 7.1 & 100 \\
\hline$x_{37}$ & 80.1 & 80.2 & 90.9 & 100 & 43.0 & 44.0 & 60.5 & 100 & 0.3 & 0.9 & 37.2 & 37.2 & 100 \\
\hline$x_{38}$ & 69.3 & 87.2 & 93.0 & 100 & 0.5 & 90.6 & 92.2 & 100 & 13.2 & 17.2 & 25.3 & 25.3 & 100 \\
\hline$x_{39}$ & 59.5 & 91.9 & 97.6 & 100 & 82.1 & 82.1 & 99.5 & 100 & 1.3 & 1.7 & 87.5 & 87.5 & 100 \\
\hline$x_{40}$ & 1.8 & 22.2 & 71.5 & 100 & 1.6 & 43.4 & 89.6 & 100 & 68.5 & 69.7 & 87.6 & 87.6 & 100 \\
\hline$X_{41}$ & 8.9 & 13.6 & 99.9 & 100 & 12.4 & 80.4 & 88.9 & 100 & 0.5 & 4.9 & 94.5 & 94.5 & 100 \\
\hline$X_{42}$ & 73.7 & 75.8 & 98.2 & 100 & 0.1 & 89.2 & 98.8 & 100 & 6.6 & 9.4 & 10.7 & 10.7 & 100 \\
\hline$x_{43}$ & 0.7 & 85.7 & 99.8 & 100 & 51.3 & 54.8 & 87.8 & 100 & 48.4 & 63.9 & 72.4 & 72.4 & 100 \\
\hline$x_{44}$ & 59.5 & 64.2 & 65.6 & 100 & 26.2 & 63.7 & 68.9 & 100 & 63.3 & 87.3 & 97.1 & 97.1 & 100 \\
\hline$X_{45}$ & 0.3 & 24.9 & 99.8 & 100 & 3.7 & 9.6 & 62.7 & 100 & 3.1 & 42.0 & 42.1 & 42.1 & 100 \\
\hline$X_{46}$ & 89.9 & 89.9 & 95.0 & 100 & 18.7 & 20.6 & 97.4 & 100 & 48.1 & 70.0 & 71.6 & 71.6 & 100 \\
\hline
\end{tabular}

showed that in the first nutrition treatment, traits relating to fat tissue were more associated than those relating to meat yield, whereas in the two remaining treatments the situation is reverse. The third singled out factor in the first and second treatment were very similar and related to traits connected to skin and bones, whereas in the third treatment this factor related to traits connected with shoulder. Fourth singled out factor was different for all three nutrition treatments which confirmed the fact that these additives in nutrition result in different slaughter characteristics of 
fattening pigs.

\section{ACKNOWLEDGEMENTS}

This work is made possible with the help of previous researches funded by the Ministry of Science and Technological Development: "Development and application of new and traditional technologies in the production of competitive food products with added value for domestic and world markets - Create wealth from the wealth of Serbia" and "Rural Labour Market and Rural Economy of Serbia - Income Diversification as a Toll to Overcome Rural Poverty."

\section{REFERENCES}

Angelov L, Vrabcheva V, Petrichev M, Borisova L (2010). The effect of copper complex of methionine compared with copper sulfate in growing pigs Turk. J. Vet. Anim. Sci. 34: 1-5.

Collins CL, Henman DJ, Dunshea FR (2007). Reduced protein intake during the weaner period has variable effects on subsequent growth and carcass composition of pigs, Aust. J. Exp. Agric. 47(11): 13331340.

Fililz A, Özkan E, Can K, Hidir D (2008). Effect of Different Diets on Growth Performance and Feed Efficiency in Early Weaned Piglets. Turk. J. Vet. Anim. Sci. 32: 7-11.

Fulgosi A (1979). Factorial analysis, School books, Zagreb.

Gardzińska A, Migdal W, Koczanovski J, Wojtysiak D, Paściak P, Zivkovic B, Tuz R (2003). Effect of body weight on histochemical profile of $\mathrm{m}$. semimembranosus fibres of fatteners. International Scientific Conference Science. Practice. Kraków, Poland, Roczniki Naukowe Zootechniki. 17(1): 41-44.

Ivanovic B (1977) Classification theory, Institute of industry economics, Belgrade.

Kosovac O, Zivkovic B, Petrovic M, Radovic C (2006). Contribution to study of evaluation of the quality of pig carcasses according to method recommended by EU with focus on withers fat thickness. Biotechnol. Anim. Husbandry, 22(5-6): 89-98.

Lakic N (1984). Model of factorial analysis in livestock production, master thesis, Faculty of Economy, Belgrade.

Maletic R (2000). Apriory methods of classification of municipalities in Serbia. Monograph, Endowment Andrejevic, Belgrade.

Nortey TN, Patience JF, Simmins PH, Trottier NL, Zijlstra RT (2007). Effects of individual or combined xylanase and phytase supplementation on energy, amino acid, and phosphorus digestibility and growth performance of grower pigs fed wheatbased diets containing wheat millrun. J. Anim Sci. 85: 1432-1443.

Ostrowska E, Cross RF, Warner RD, Muralitharan M, Bauman DE, Dunshea FR (2005). Dietary conjugated linoleic acid improves carcass leanness without altering meat quality in the growing pig. Australian J. Exp. Agric. 45(6): 691-69.

Popovic B (2001). Correlation analysis of conditions and results of production on combined agricultural households. Master thesis, Zemun.
Popovic B (2005). Factorial analysis of conditions and results of production on combined agricultural households. Agric. Econs. Belgrade. 52 (3) 371-383.

Radovic C, Petrovic M, Zivkovic B, Kosovac O, Radojkovic D, Mijatovic M, Stojanovic Lj (2007). Effect of different fixed factors on pig carcass quality traits. Biotechnol. Anim. Husbandry, 23(1-2): 71-80.

Ralevic N, Ljubanovic-Ralevic I, Rajic Z, Popovic B (2006). Application of factorial analysis for determination of indicators for identification of white cheeses in brine, Chapter in monograph Autochthonous hite cheeses in brine Faculty Agric., Belgrade, pp. 113-143.

Stankovic J, Antonijevic N, Ralevic N, Vitorovic D (1985). Factorial analysis of some anatomical properties of hybrids PRELUX-BRO, ROSS-1 and VEDETTE, Vet. Bull. 39: 61-67.

Zivkovic B, Migdal W, Petrovic M, Radovic C, Kosovac O, Fabjan M, Josipovic S, Maletic R (2006a). The effect of introduction of some additives in fattening pig diets on slaughter results and meat quality. Animal Science (an international journal of fundamental and applied research), Official J. Br. Soc. Anim. Sci. BSAS. 1: 166-167.

Zivkovic B, Petrovic M, Kosovac O, Radovic C, Fabjan M (2006b). Effect of use of Vitaprotein 50 as fish meal substitute in nutrition of growing-fattening pigs. The 35th International Session of Scientific Communications. The Scientific Papers Faculty Anim. Sci. Bucharest. pp. 171-175.

Zivkovic B, Stanojlovic R, Migdal W, Radovic C, Fabjan M, Kosovac O, Todorovic-Joksimovic M (2006c). Additives Lacture and Microbond in nutrition of sows and piglets. Forage, Zagreb, Croatia. 48: 251-259.

Zivkovic B, Nikic D, Migdal W, Radovic C, Fabjan M, Kosovac O, Pejcic $S$ (2006d). Probiotic Beta Plus in nutrition of sows and piglets. Biotechnol. Anim. Husbandry, 22(1-2): 109-117.

Zivkovic B, Migdal W, Radovic C, Fabjan M, Petrovic M, Kosovac O (2004a). Effect of some growth promoters on carcass quality of growing-fattening pigs. International Conference Pig and Poultry meat safety and quality-genetic and non-genetic factors, Krakow: $p$. 71.

Zivkovic B, Migdal W, Fabjan M, Kovcin S, Radovic C, Kosovac O, Todorovic M, Jokic Z (2004b). Nutritive value of probiotics in nutrition of fattening pigs. Biotechnol. Anim. Husbandry, 20(1-2): 51-58.

Zivkovic B, Migdal W, Fabjan M, Radovic C (2003a). Probiotic in nutrition of sows and suckling piglets. International Scientific Conference Science Practice. Kraków, Poland. Roczniki Naukowe Zootechniki, 17/(1): 309-313.

Zivkovic B, Petrovic M, Fabjan M, Radovic C (2003b). The effect of certain nutritive supplements on the viability of piglets. 9th Bernburger Biotechnik Workshop, Das Saugferkel, Bernburg. pp. 117-121.

Zivkovic B, Migdal W, Saftic M, Radovic C, Fabjan M, Miljevic Z (2003c). Aromatic substances additives in nutrition of sows and suckling piglets. Biotechnol. Anim. Husbandry, 19(5-6): 271-276.

Xin L, Jianlei F, Zirong X, Yaping L, Yuanyuan L (2007). The Effects of Fermented Soybean Meal on Growth Performance and Immune Characteristics in Weaned Piglets, Turk. J. Vet. Anim. Sci. 31: 341345.

Winiarska-Mieczan A, Kwiecien M (2010). The effectiveness of grass pea (Lathyrus sativus L.) seeds in pig feed. Turk. J. Vet. Anim. Sci. 34: 155-162. 